\title{
In Vitro Antibacterial and Antiproliferative Potential of Echinops lanceolatus Mattf. (Asteraceae) and Identification of Potential Bioactive Compounds
}

\author{
Armel Jackson Seukep ${ }^{1,2,3,4} \mathbb{C}$, Yong-Li Zhang ${ }^{1,3,4}$, Yong-Bing $X u^{1,3,4}$ and \\ Ming-Quan Guo 1,3,4,*(D) \\ 1 CAS Key Laboratory of Plant Germplasm Enhancement and Specialty Agriculture, Wuhan Botanical Garden, \\ Chinese Academy of Sciences, Wuhan 430074, China; seukepp@yahoo.fr (A.J.S.); \\ zhangyongli@wbgcas.cn (Y.-L.Z.); xuyongbing17@mails.ucas.ac.cn (Y.-B.X.) \\ 2 Department of Biomedical Sciences, Faculty of Health Sciences, University of Buea, P.O. Box 63, Buea, \\ Cameroon \\ 3 Sino-Africa Joint Research Center, Chinese Academy of Sciences, Wuhan 430074, China \\ 4 Innovation Academy for Drug Discovery and Development, Chinese Academy of Sciences, Shanghai 201203, \\ China \\ * Correspondence: guomq@wbgcas.cn; Tel./Fax: +86-027-8770-0850
}

Received: 28 February 2020; Accepted: 20 March 2020; Published: 30 March 2020

\begin{abstract}
Many species belonging to the genus Echinops are widely used in traditional medicine to treat infectious diseases and cancers. The present study aimed to evaluate the antibacterial and antiproliferative properties of Echinops lanceolatus Mattf. (Asteraceae). The activity of the methanolic extract and subsequent partition fractions was investigated against drug-resistant bacteria (Gram-negative and Gram-positive) and human tumor cell lines using broth microdilution and sulforhodamine B (SRB) assay, respectively. Our findings revealed weak to moderate antibacterial activities of tested extracts, with the recorded minimal inhibitory concentrations ranging from 256 to $1024 \mu \mathrm{g} / \mathrm{mL}$. The ethyl acetate fraction (EL-EA) was found to be the most effective. Likewise, that fraction displayed strong antiproliferative potential with recorded $\mathrm{IC}_{50}$ of $8.27 \mu \mathrm{g} / \mathrm{mL}$ and $28.27 \mu \mathrm{g} / \mathrm{mL}$ on A549 and HeLa cells, respectively. An analysis based on the ultra-performance liquid chromatography-electrospray ionization tandem mass spectrometry (UPLC-ESI-MS/MS) of the EL-EA fraction allowed the identification of 32 compounds, of which quinic acid and derivatives, cinnamic acid derivatives, dihydrokaempferol, naringenin-7-O-glucoside, apigenin-7-O-D-glucoside, naringin, apigenin, rhoifolin, coniferyl aldehyde, and secoisolariciresinol are well-known compounds of biological importance. This study is first to report on the biological activity and phytochemical profile of E. lanceolatus. We provide a baseline to consider E. lanceolatus as a valuable source of anti-infective and antiproliferative agents.
\end{abstract}

Keywords: Echinops lanceolatus; antimicrobial; cytotoxicity; UPLC-ESI-MS/MS

\section{Introduction}

The resurgence of drug-resistant infectious diseases, as well as cancers, propels the scientific community to seek alternative medicine. This double burden is indeed a serious public health-threatening worldwide [1]. As part of the implementation of the Global Action Plan on antimicrobial resistance (AMR), the World Health Organization (WHO) caught up with a list of priority antibiotic-resistant pathogens to guide research into and the discovery and development of new therapeutic agents. Some bacteria, listed as a critical priority, are the members of the group named ESKAPEE (Enterococcus spp., Staphylococcus aureus, Klebsiella pneumoniae, Acinetobacter baumannii, 
Pseudomonas aeruginosa, Enterobacter spp., and Escherichia coli) [2,3]. Yet, alternative strains like Salmonella species are also of clinical concern. Botanicals are broadly recognized as some of the most prolific sources of leads for the development of new drug candidates. They cover a large spectrum of therapeutic uses with a great diversity of chemical structures. The scientific community still considers exploring medicinal plants for new drug discovery. The application of molecular, analytical, and computational techniques has raised the availability of novel compounds that can be handily isolated from natural sources [4,5]. Many species memberships to the genus Echinops are used in traditional medicine, primarily in Africa and Asia, to treat various ailments including infectious and respiratory diseases, inflammation, and to relieve pain. They are also claimed to have aphrodisiac properties, to fasten expulsion of the placenta, and to act on the kidney for the elimination of renal stones. More than 151 compounds have been isolated from the Echinops genus including thiophenes, terpenes, flavonoids, and other phenolic compounds, phenylpropanoids, alkaloids, and lipids [6]. Varied extracts, isolated compounds, and essential oils from members of this genus were found to exert multiple biological properties including anti-infective, antiproliferative, antioxidant, and anti-inflammatory [6]. However, several species belonging to this genus are claimed to have traditional medicinal uses but their biological effect not yet been investigated. It is the case of the member examined in the present study namely Echinops lanceolatus.

Echinops lanceolatus Mattf. (Asteraceae) is a native plant to Cameroon, Central African Republic, and Nigeria [7]. E. lanceolatus is a spiny perennial herb, chamaephytes, with marcescent leaves. It is a much-branched herb with stout stems $2-3 \mathrm{ft}$. high from a woody stock. Florets are blue or white in spherical heads up to 2 in. across. This plant species is widely distributed in open grassland including West Tropical Africa $[7,8]$. To the best of our knowledge, no biological activities, nor phytochemical studies have been reported on this plant species. In the present investigation, as part of our continuing search for potent therapeutic agents from natural sources, we assessed their antibacterial and antiproliferative potential. Assays were performed against the ESKAPEE group's bacteria and Salmonella enterica, and human tumor cell lines (HepG2, HeLa, HT-29, and A549). The ultra-performance liquid chromatography (UPLC) coupled to electrospray ionization tandem mass spectrometry (ESI-MS/MS) analysis was applied for the identification of the potential bioactive chemical components of the ethyl acetate fraction (EL-EA), the most active extract. Compounds were tentatively identified based on the comparison of their ESI-MS ${ }^{2}$ data with the corresponding standards and fragmentation pathways from databases (ChemSpider, HMDB, PubChem, mzCloud, and mzVault) and/or data available in the literature. To the best of our knowledge, the present study reports for the first time the biological properties of E. lanceolatus and their phytochemical profile. This, therefore, provides a baseline for thorough investigations for the isolation, purification, and development of potent phytomedicine against the double burden of infectious diseases and tumors.

\section{Results}

\subsection{Antibacterial Potential}

Results of bacterial susceptibility testing to E. lanceolatus extracts are summarized in Table 1. Methanolic extract (EL-MeOH) and fractions depicted selective inhibitory effects depending on the studied bacteria strain, with minimal inhibitory concentrations (MICs) varying from 256 to $1024 \mu \mathrm{g} / \mathrm{mL}$. The lowest MIC value of $256 \mu \mathrm{g} / \mathrm{mL}$ was recorded with EL-EA against S. enterica. EL-EA exhibited the highest spectrum of inhibition, acting against $6 / 8$ of studied bacteria, followed by the dichloromethane (EL-DCM) fraction (5/8). EL-MeOH and other fractions ( $n$-hexane and $n$-butanol) exerted the activity on $4 / 8$ bacteria strains. Interestingly, EL-MeOH, and all subsequent partition fractions, prevented the growth of S. enterica, E. cloacae, and S. aureus. A bactericidal effect (minimal bactericidal concentration $(\mathrm{MBC})=1024 \mu \mathrm{g} / \mathrm{mL}$ ) was recorded with EL-EA on S. aureus. 
Table 1. MIC and MBC $(\mu \mathrm{g} / \mathrm{mL})$ of E. lanceolatus extracts.

\begin{tabular}{|c|c|c|c|c|c|c|c|}
\hline \multicolumn{2}{|c|}{ Bacteria Strains } & \multicolumn{5}{|c|}{ MIC and MBC $(\mu \mathrm{g} / \mathrm{mL})$ of Echinops lanceolatus Extracts * } & \multirow{2}{*}{$\begin{array}{l}\text { ATB } \\
\text { STR }\end{array}$} \\
\hline & & $\mathrm{MeOH}$ & Hex & DCM & EA & $\mathrm{BuOH}$ & \\
\hline \multirow{3}{*}{ Gram-negative } & Salmonella enterica & 1024 & 512 & 512 & 256 & 1024 & 4 \\
\hline & Enterobacter cloacae & 1024 & 1024 & 1024 & 512 & 1024 & 64 \\
\hline & Klebsiella pneumoniae & 1024 & 1024 & 1024 & $>1024$ & $>1024$ & $>256$ \\
\hline \multirow{2}{*}{ Gram-positive } & Staphylococcus aureus & 1024 & 1024 & 512 & $512(1024)^{B}$ & 1024 & 4 \\
\hline & Enterococcus faecalis & $>1024$ & $>1024$ & $>1024$ & $>1024$ & $>1024$ & 256 \\
\hline
\end{tabular}

${ }^{*}$ Each fraction tested in triplicate, at $1024 \mu \mathrm{g} / \mathrm{mL}$. Reference antibiotic (ATB) Streptomycin (STR) tested at $256 \mu \mathrm{g} / \mathrm{mL}$. MIC: Minimal Inhibitory Concentration; MBC: Minimal Bactericidal Concentration. ${ }^{B}$ : Bactericidal effect (MBC/MIC <4). MeOH: Methanol, Hex: $n$-Hexane, DCM: Dichloromethane, EA: Ethyl acetate, BuOH: $n$-Butanol.

\subsection{The Antiproliferative Potential of E. lanceolatus}

The percentage of tumor cell growth inhibition of studied samples is shown in Figure 1. At a fixed concentration of $100 \mu \mathrm{g} / \mathrm{mL}, \mathrm{EL}-\mathrm{MeOH}$ and fractions from E. lanceolatus displayed antiproliferative activity depending on studied cells. EL-EA was found to be the most potent, displaying significant inhibition of $72 \%$ and $71 \%$ on HepG 2 and A549, respectively.

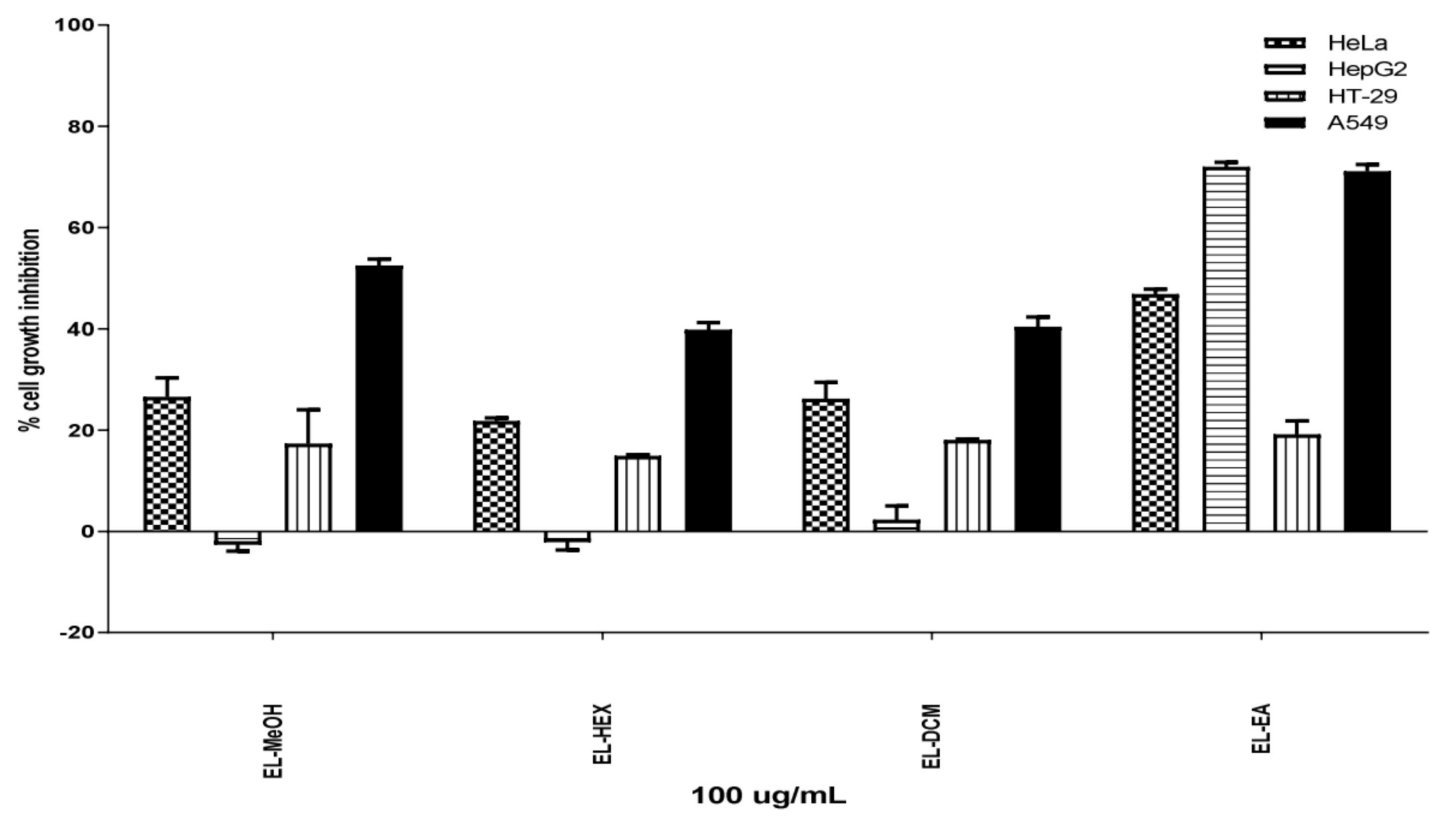

Figure 1. Percentage of cell growth inhibition of E. lanceolatus extracts. Data are expressed as mean \pm SEM, $p<0.05$.

Furthermore, a concentration-dependent effect of EL-EA (tested at concentrations ranging from 0.82 to $200 \mu \mathrm{g} / \mathrm{mL}$ ) was studied on HepG2, A549, HeLa, and HT-29 cell lines for $48 \mathrm{~h}$. The results revealed a dose-dependent inhibition of tumor cell growth (Figure 2). The $\mathrm{IC}_{50}$ values ranged from 8.27 to $76.91 \mu \mathrm{g} / \mathrm{mL}$. The lowest $\mathrm{IC}_{50}$ value (significant activity) of $8.27 \mu \mathrm{g} / \mathrm{mL}$ recorded on A549. 
(a)

HeLa EL-EA 48h

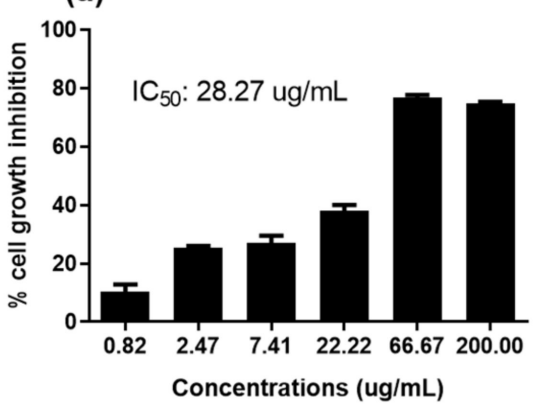

(c) HT-29 EL-EA 48h

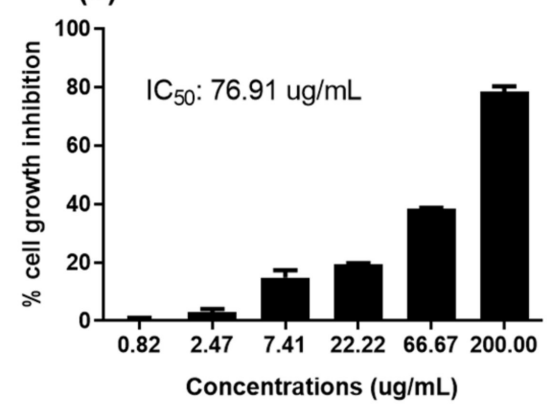

(b)

HepG2 EL-EA 48h

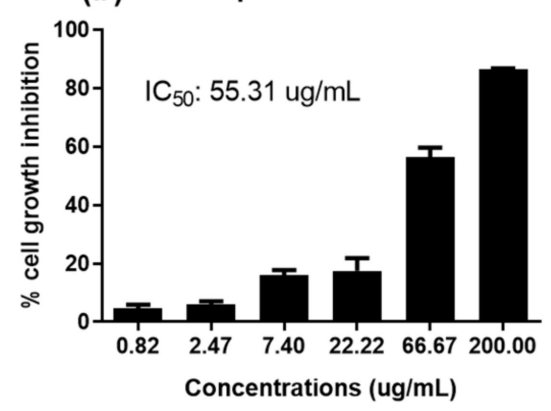

(d) A549 EL-EA 48h

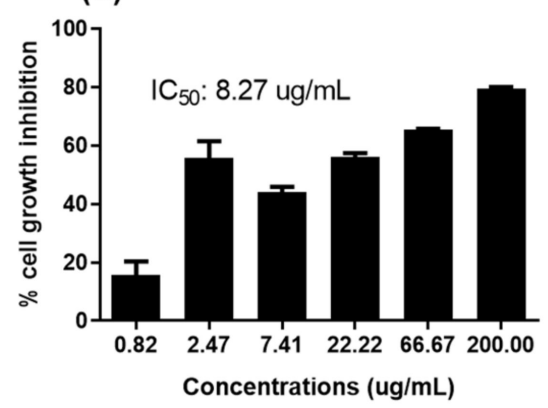

Figure 2. Concentration-dependent antiproliferative activities of EL-EA against (a) HeLa, (b) HepG2, (c) HT-29, and (d) A549 human tumor cell lines. Cells incubated with extract for $48 \mathrm{~h}$. IC 50 : half-maximal inhibitory concentration. EL-EA: E. lanceolatus ethyl acetate fraction. HepG2 (human liver cancer cell line), HeLa (cervical cancer cells), HT-29 (human colon cancer cell line), and A549 (adenocarcinomic human alveolar basal epithelial cells). Data are expressed as mean \pm SEM, $p<0.05$.

\subsection{UPLC-ESI-MS/MS Analysis of EL-EA Fraction}

To explore the potential bioactive compounds in the EL-EA fraction, which may be responsible for the recorded biological activities, a study of the EL-EA fraction was conducted based on UPLC-ESI-MS/MS in the negative ion mode. The analysis led to the detection of several peaks in that fraction, of which 32 compounds were identified with high-resolution MS and MS/MS data (Figure 3). Compounds corresponding to Peaks 1 to 24 were identified by comparison of the mass spectra with the available standards from databases (ChemSpider, mzCloud, mzVault, HDMB, and PubChem) and the literature data; identification of Peaks 25 to 32 was only based on available standards from databases. The retention times (Rt), molecular formula, and $\mathrm{MS}^{2}$ data are condensed in Table 2. Some major peaks found between 9 and 10,13 and 14,17 and 18, 19 and 20, 20 and 21, 22 and 23, 25 and 26, 26 and 27, 27 and 28, 29 and 30, 30 and 31, and after Peak 31 (Figure 1) were not identified. Subject to further studies, we can hypothesize that the corresponding unidentified compounds may be new. The phytochemicals successfully identified were mainly phenolic acids, polyphenols (flavonoids and lignan), organic acids, and fatty acids, as detailed below. The chemical structures of some well-known identified compounds of biological importance are shown in Figure 4. 
Table 2. Identified compounds from the E. lanceolatus EA fraction corresponding to the base peak chromatogram (BPC) in Figure 3.

\begin{tabular}{|c|c|c|c|c|c|c|}
\hline Peak & $\underset{(\mathbf{m i n})}{\mathbf{R t}}$ & {$[\mathbf{M}-\mathrm{H}]^{-}(m / z)$} & MF & $\operatorname{MS}^{2}(m / z)$ & Identification * & Ref \\
\hline 1 & 1.16 & 117.0180 & $\mathrm{C}_{4} \mathrm{H}_{6} \mathrm{O}_{4}$ & $117.0179,99.0074,73.0282$ & Succinic acid & [9] \\
\hline 2 & 1.22 & 191.0551 & $\mathrm{C}_{7} \mathrm{H}_{12} \mathrm{O}_{6}$ & $191.0552,173.0453,127.0388,93.0333,85.0282$ & Quinic acid & [10] \\
\hline 3 & 1.34 & 153.0181 & $\mathrm{C}_{7} \mathrm{H}_{6} \mathrm{O}_{4}$ & $152.9947,109.0282,108.0201$ & Dihydroxybenzoic acid & [11] \\
\hline 4 & 1.53 & 167.0338 & $\mathrm{C}_{8} \mathrm{H}_{8} \mathrm{O}_{4}$ & $167.0334,152.0104,123.0440,108.0204,91.0177$ & Hydroxy-methoxy-benzoic acid isomer 1 & [11] \\
\hline 5 & 1.69 & 179.0339 & $\mathrm{C}_{9} \mathrm{H}_{8} \mathrm{O}_{4}$ & $179.0553,135.0442$ & Dihydroxycinnamic acid isomer 1 & [11] \\
\hline 6 & 2.15 & 167.0338 & $\mathrm{C}_{8} \mathrm{H}_{8} \mathrm{O}_{4}$ & $167.0334,152.0104,123.0440,108.0204,91.0177$ & Hydroxy-methoxy-benzoic acid isomer 2 & [11] \\
\hline 7 & 2.44 & 179.0338 & $\mathrm{C}_{9} \mathrm{H}_{8} \mathrm{O}_{4}$ & $179.0553,135.0442$ & Dihydroxycinnamic acid isomer 2 & [11] \\
\hline 8 & 3.08 & 163.0389 & $\mathrm{C}_{9} \mathrm{H}_{8} \mathrm{O}_{3}$ & $163.0390,120.0523,119.0490$ & Coumaric acid isomer 1 & [11] \\
\hline 9 & 3.29 & 163.0389 & $\mathrm{C}_{9} \mathrm{H}_{8} \mathrm{O}_{3}$ & $163.0390,120.0523,119.0490$ & Coumaric acid isomer 2 & [11] \\
\hline 10 & 4.58 & 187.0965 & $\mathrm{C}_{9} \mathrm{H}_{16} \mathrm{O}_{4}$ & $187.0963,125.0960,97.0643$ & Nonanedioic acid & [12] \\
\hline 11 & 5.70 & 137.0231 & $\mathrm{C}_{7} \mathrm{H}_{6} \mathrm{O}_{3}$ & $137.0232,93.0333,71.4599$ & 3-Hydroxybenzoic acid & [11] \\
\hline 12 & 5.97 & 337.0924 & $\mathrm{C}_{16} \mathrm{H}_{18} \mathrm{O}_{8}$ & $191.0552,173.0444,163.0389,119.0489,93.0332$ & 5-Coumaroylquinic acid & [13] \\
\hline 13 & 6.67 & 367.1027 & $\mathrm{C}_{17} \mathrm{H}_{20} \mathrm{O}_{9}$ & $367.1055,193.0497,191.0553,173.0444,134.0361,93.0330$ & 5-Feruloyl quinic acid & [14] \\
\hline 14 & 7.67 & 515.1187 & $\mathrm{C}_{25} \mathrm{H}_{24} \mathrm{O}_{12}$ & $353.0876,191.0553,179.0340,161.0234,135.0439,93.0332,85.0282$ & Dicaffeoylquinicacid isomer 1 & [15] \\
\hline 15 & 7.94 & 515.1186 & $\mathrm{C}_{25} \mathrm{H}_{24} \mathrm{O}_{12}$ & $353.0874,191.0552,179.0340,173.0445,135.0439,93.0332,85.0282$ & Dicaffeoylquinicacid isomer 2 & [15] \\
\hline 16 & 8.29 & 515.1189 & $\mathrm{C}_{25} \mathrm{H}_{24} \mathrm{O}_{12}$ & $515.1190,353.0875,191.0552,179.0340,173.0445,161.0233,135.0439$ & Dicaffeoylquinicacid isomer 3 & [15] \\
\hline 17 & 8.72 & 515.1189 & $\mathrm{C}_{25} \mathrm{H}_{24} \mathrm{O}_{12}$ & $515.1190,353.0875,191.0552,179.0340,173.0445,135.0439,93.0333$ & Dicaffeoylquinicacid isomer 4 & [15] \\
\hline 18 & 9.04 & 287.0556 & $\mathrm{C}_{15} \mathrm{H}_{12} \mathrm{O}_{6}$ & $287.0921,259.0608,243.0658,201.0549,177.0547,151.0025,125.0231$ & Dihydrokaempferol & [16] \\
\hline 19 & 9.33 & 433.1134 & $\mathrm{C}_{21} \mathrm{H}_{22} \mathrm{O}_{10}$ & $433.1120,313.0716,271.0608,177.0181,151.0025,119.0489,107.0125$ & Naringenin-7-O-glucoside & [17] \\
\hline 20 & 9.59 & 431.0977 & $\mathrm{C}_{21} \mathrm{H}_{20} \mathrm{O}_{10}$ & $431.0980,269.0441,268.0373,240.0422,211.0392,151.0025,117.0333$ & Apigenin-7-O-glucoside & [18] \\
\hline 21 & 10.53 & 177.0546 & $\mathrm{C}_{10} \mathrm{H}_{10} \mathrm{O}_{3}$ & $177.0547,162.0312,145.0283,133.0283,123.0439,121.0282,117.0333$ & Coniferyl aldehyde & [19] \\
\hline 22 & 10.61 & 579.1503 & $\mathrm{C}_{27} \mathrm{H}_{32} \mathrm{O}_{14}$ & $579.1474,307.0825,271.0610,145.0283,119.0490,117.0334$ & Naringin & [20] \\
\hline 23 & 10.86 & 577.1346 & $\mathrm{C}_{27} \mathrm{H}_{30} \mathrm{O}_{14}$ & $577.1351,431.0982,269.0453,145.0284,117.0333$ & Rhoifolin & [20] \\
\hline 24 & 11.02 & 269.0451 & $\mathrm{C}_{15} \mathrm{H}_{10} \mathrm{O}_{5}$ & $269.0451,225.0551,151.0025,117.0332$ & Apigenin & [21] \\
\hline 25 & 11.12 & 329.2328 & $\mathrm{C}_{18} \mathrm{H}_{34} \mathrm{O}_{5}$ & $329.2331,311.2234,229.1438,211.1332,171.1016,139.1117,99.0802$ & (-)-Pinellic acid & 1 \\
\hline 26 & 11.87 & 361.0818 & $\mathrm{C}_{20} \mathrm{H}_{26} \mathrm{O}_{6}$ & $361.0820,288.0636,269.0451,163.0390,145.0283,117.0333$ & (-)-Secoisolariciresinol & / \\
\hline 27 & 13.09 & 293.2117 & $\mathrm{C}_{18} \mathrm{H}_{30} \mathrm{O}_{3}$ & $293.2119,265.2168$ & 13-Keto-9Z,11E-octadecadienoic acid & / \\
\hline 28 & 13.45 & 295.2273 & $\mathrm{C}_{18} \mathrm{H}_{32} \mathrm{O}_{3}$ & $295.2273,251.2378$ & 13S-Hydroxyoctadecadienoic acid & / \\
\hline 29 & 13.69 & 275.1647 & $\mathrm{C}_{17} \mathrm{H}_{24} \mathrm{O}_{3}$ & $275.1648,215.1434,59.0125$ & Cyclandelate & / \\
\hline 30 & 14.17 & 277.2166 & $\mathrm{C}_{18} \mathrm{H}_{30} \mathrm{O}_{2}$ & 277.2166 & $\alpha$-Linolenic acid & l \\
\hline 31 & 14.63 & 255.2324 & $\mathrm{C}_{16} \mathrm{H}_{32} \mathrm{O}_{2}$ & 255.2326 & Ethyl myristate & / \\
\hline 32 & 14.74 & 281.2479 & $\mathrm{C}_{18} \mathrm{H}_{34} \mathrm{O}_{2}$ & 281.1389 & Oleic acid & / \\
\hline
\end{tabular}

MF: Molecular Formula. Rt: Retention time. Ref: Reference. ${ }^{*}$ Compounds corresponding to Peaks 1 to 24 were identified by comparison of the mass spectra with the available standards from databases (ChemSpider, mzCloud, mzVault, HDMB, and PubChem) and the literature data, whilst identification of Peaks 25 to 32 was only based on available standards from databases. 


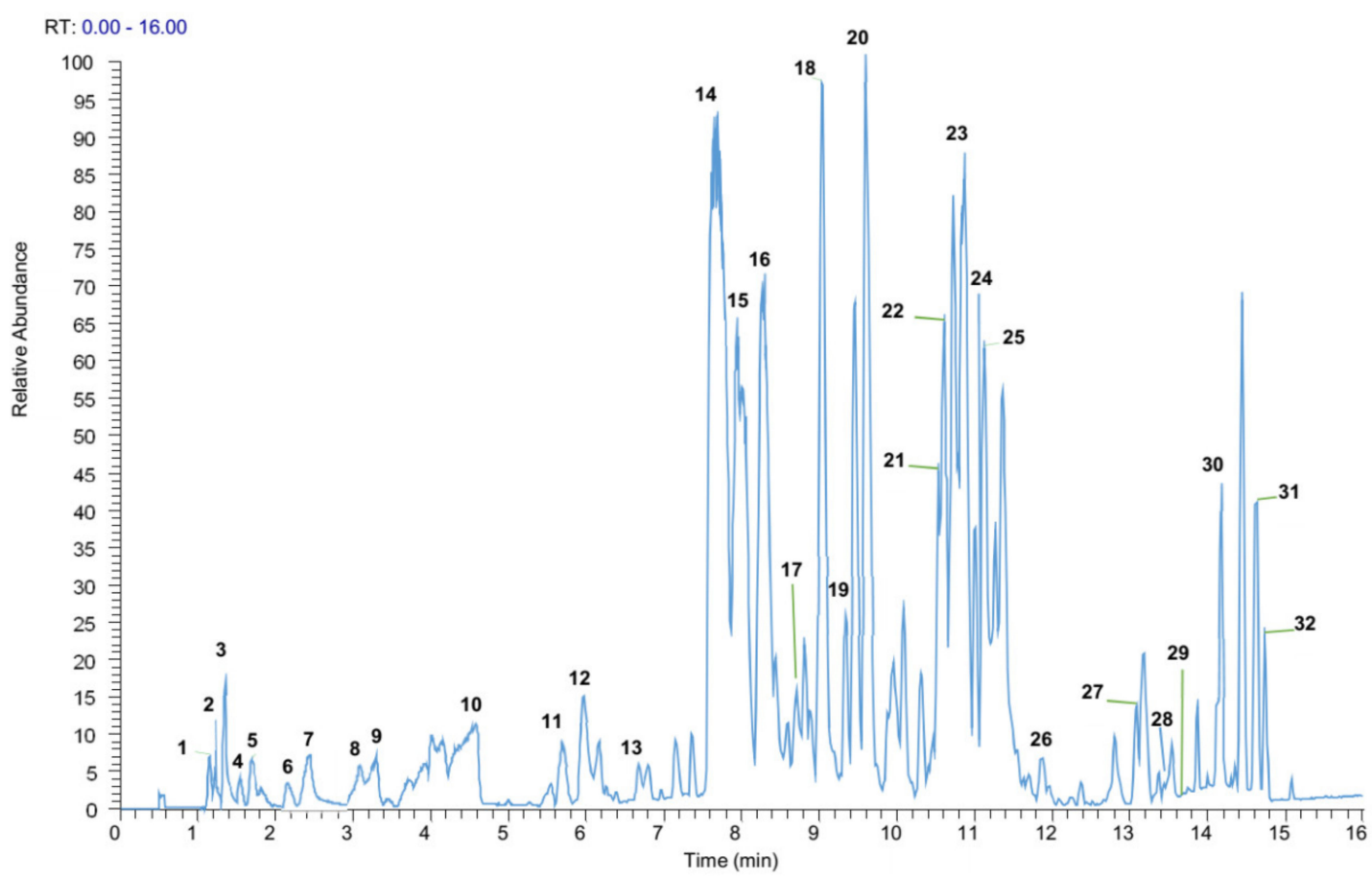

Figure 3. Ultra-performance liquid chromatography-electrospray ionization tandem mass spectrometry (UPLC-ESI-MS/MS) base peak chromatogram of the E. lanceolatus EA fraction. The peak numbers in this figure correspond to those used in Table 2.<smiles>O=C1c2c(O)cc(O)cc2O[C@H](c2ccc(O)cc2)C1O</smiles><smiles>CCCCCCC=O</smiles><smiles>COc1cc(CC(CO)C(CO)Cc2ccc(O)c(OC)c2)ccc1O</smiles>

Secoisolariciresinol<smiles>O=c1cc(-c2ccc(O)cc2)oc2cc(O)cc(O)c12</smiles><smiles>O=c1cc(-c2ccc(O)cc2)oc2cc(OC3OC4OC3C(O)C(O)C4O)cc(O)c12</smiles><smiles>O=c1cc(-c2ccc(O)cc2)oc2cc(OC3OC(O)C4OC(C3O)C(O)C(O)C4O)cc(O)c12</smiles><smiles>COCCO</smiles>
Rhoifolin<smiles>O=C1C[C@H](c2ccc(O)cc2)Oc2cc(OC(O)C(O)C(O)O)cc(O)c21</smiles>

Naringenin-7-O-glucoside<smiles>CC(O)C(O)CCOc1cc(O)c2c(c1)O[C@H](c1ccc(O)cc1)CC2=O</smiles>

Figure 4. The chemical structures of some well-known identified compounds of biological importance from the E. lanceolatus EA fraction.

\subsubsection{Phenolic Acids}

Peak 2 was identified as d-(-)-quinic acid, which showed an [M-H] $]^{-}$ion at $m / z$ 191.0551. Identified quinic derivatives (or conjugates) included 5-coumaroylquinic acid, which showed an $[\mathrm{M}-\mathrm{H}]^{-}$ion at $\mathrm{m} / \mathrm{z}$ 337.0924 (Peak 12), a 5-feruloyl quinic acid [M-H] ${ }^{-}$ion at $m / z 367.1027$ (Peak 13), a dicaffeoylquinicacid (DCQ) isomer 1 [M-H] $^{-}$ion at $m / z 515.1187$ (Peak 14), a DCQ isomer $2[\mathrm{M}-\mathrm{H}]^{-}$ion at $m / z 515.1186$ (Peak 15), and a DCQ isomers 3 and 4 [M-H] $]^{-}$ion at $m / z 515.1189$ (Peaks 16 and 17, respectively). 
Other phenolic acids included a dihydroxybenzoic acid $[\mathrm{M}-\mathrm{H}]^{-}$ion at $\mathrm{m} / \mathrm{z} 153.0181$ (Peak 3), a hydroxy-methoxy-benzoic acid isomers 1 and $2[\mathrm{M}-\mathrm{H}]^{-}$ion at $\mathrm{m} / \mathrm{z} 167.0338$ (Peaks 4 and 6, respectively), and a 3-hydroxybenzoic acid $[\mathrm{M}-\mathrm{H}]^{-}$ion at $\mathrm{m} / \mathrm{z} 137.0231$ (Peak 11). The identified cinnamic acid derivatives comprised dihydroxycinnamic acid isomers 1 (Peak 5, $[\mathrm{M}-\mathrm{H}]^{-}$ion at $\mathrm{m} / \mathrm{z} 179.0339$ ) and 2 (Peak 7, $[\mathrm{M}-\mathrm{H}]^{-}$ion at $\mathrm{m} / \mathrm{z}$ 179.0338), and a coumaric acid isomers 1 and $2[\mathrm{M}-\mathrm{H}]^{-}$ion at $\mathrm{m} / \mathrm{z} 163.0389$ (Peaks 8 and 9, respectively). Peak 21 was identified as coniferyl aldehyde, which showed an $[\mathrm{M}-\mathrm{H}]^{-}$ ion at $m / z$ 177.0546.

\subsubsection{Polyphenols}

Flavonoids

Peak 18 was identified as dihydrokaempferol $\left([\mathrm{M}-\mathrm{H}]^{-}\right.$ion at $\left.\mathrm{m} / \mathrm{z} 287.0556\right)$, a flavanonol. Peaks 19 and 22 were two flavanone glycosides, namely a naringenin-7-O-glucoside (prunin) $\left([\mathrm{M}-\mathrm{H}]^{-}\right.$ion at $m / z 433.1134$ ) and a naringin ([M-H $]^{-}$ion at $\left.m / z 579.1503\right)$, respectively. Peak 24 was identified as an apigenin $\left([\mathrm{M}-\mathrm{H}]^{-}\right.$ion at $\left.m / z 269.0451\right)$. Two other memberships of apigenin family have been also detected, corresponding to Peak 20 (apigenin-7-O- $\beta$-D-glucoside (cosmosiin or apigetrin), $[\mathrm{M}-\mathrm{H}]^{-}$ion at $m / z$ 431.0977) and Peak 23 (rhoifolin, [M-H] $]^{-}$ion at $m / z$ 577.1346).

Lignan

Peak 26 was identified as (-)-secoisolariciresinol, which showed an $[\mathrm{M}-\mathrm{H}]^{-}$ion at $\mathrm{m} / \mathrm{z} 361.0818$.

\subsubsection{Organic Acids and Fatty Acids}

The identified organic acids included carboxylic acids namely a succinic acid $[\mathrm{M}-\mathrm{H}]^{-}$ion at $\mathrm{m} / \mathrm{z}$ 117.0180 (Peak 1), a nonanedioic acid $[\mathrm{M}-\mathrm{H}]^{-}$ion at $\mathrm{m} / \mathrm{z} 187.0965$ (Peak 10), and a cyclandelate $[\mathrm{M}-\mathrm{H}]^{-}$ ion at $\mathrm{m} / \mathrm{z} 275.1647$ (Peak 29). The fatty acids found were a (-)-pinellic acid [M-H] $]^{-}$ion at $\mathrm{m} / \mathrm{z} 329.2328$ (Peak 25), polyunsaturated fatty acids including a 13-KODE (13-Keto-9Z,11E-octadecadienoic acid) $[\mathrm{M}-\mathrm{H}]^{-}$ion at $\mathrm{m} / \mathrm{z} 293.21$ (Peak 27), a 13-HODE (13S-hydroxyoctadecadienoic acid) [M-H] ${ }^{-}$ion at $\mathrm{m} / \mathrm{z} 293.2117$ (Peak 28), and an alpha-linolenic acid [M-H] $]^{-}$ion at $\mathrm{m} / \mathrm{z} 277.2166$ (Peak 30, tentatively). Peak 31 was tentatively identified as an ethyl myristate $[\mathrm{M}-\mathrm{H}]^{-}$ion at $\mathrm{m} / \mathrm{z} 255.2324$, a long-chain saturated fatty acid. Peak 32 was tentatively identified as an oleic acid $[\mathrm{M}-\mathrm{H}]^{-}$ion at $\mathrm{m} / \mathrm{z} 281.2479$, a C18 monounsaturated fatty acid.

\section{Discussion}

Our study included the ESKAPEE group's bacteria and S. enterica. These bacteria are known to express high resistance to traditional antibiotics [3,22]. The WHO [2], in the context of research for efficient therapeutic agents against AMR, gave priority to these bacteria of clinical concern for antibacterial research. These, therefore, represent the good models in the search of alternative medicine to combat drug resistance. The antibiotic resistance profile of studied bacteria was ascertained during preliminary investigations (data not shown). Medicinal plant extracts are routinely classified as highly active if the MIC $<100 \mu \mathrm{g} / \mathrm{mL}$, moderately active when $100 \leq$ MIC $\leq 625 \mu \mathrm{g} / \mathrm{mL}$, and weakly active if MIC $\geq 625 \mu \mathrm{g} / \mathrm{mL}$ [23]. According to these interpretive criteria, it can be deduced that EL-MeOH and the subsequent partition fractions displayed weak to moderate antibacterial activities based on MIC values obtained. The moderate activity was recorded with EL-EA against $S$. enterica $(\mathrm{MIC}=256 \mu \mathrm{g} / \mathrm{mL}$ ), E. cloacae, and S. aureus $(\mathrm{MIC}=512 \mu \mathrm{g} / \mathrm{mL}$ ); EL-DCM against S. aureus $(\mathrm{MIC}=512 \mu \mathrm{g} / \mathrm{mL}$ ); EL-Hex and EL-BuOH fractions against S. enterica and E. coli $(\mathrm{MIC}=512 \mu \mathrm{g} / \mathrm{mL}$ ), respectively (Table 1$)$. The $\mathrm{EL}-\mathrm{MeOH}$, as a complex mixture of chemical components, was less active than derived fractions. These indicate that partitioning by successive depletion enhances the biological activity of E. lanceolatus. All fractions were found effective against S. enterica and S. aureus. These bacteria are common food-borne pathogens causing gastrointestinal (GIT) troubles [24]. The present study underscores evidence of the traditional use of Echinops L. in the treatment of GIT troubles. Most of the studied bacterial strains were 
Gram-negative. The latter is found most resistant compared to their counter-part Gram-positive ones, owed to the presence of an outer membrane. The outer membrane gives Gram-negative bacteria an increased ability to reduce the penetration of antibacterial molecules across the membrane, leading to intrinsic resistance to many molecules including therapeutic agents [25,26]. The differences of sensitivity recorded for the same extract with different bacteria strains could be due to intrinsic differences in the chemical composition of the bacterial cell wall [26]. Otherwise, the differences obtained for the same bacterium and the different fractions suggest the qualitative and quantitative differences in antibacterial active principles or different action mechanisms of biologically active components.

The cytotoxicity of a plant extract on cancer cell lines is considered significant or strong when $\mathrm{IC}_{50}$ $<20 \mu \mathrm{g} / \mathrm{mL}$, moderate if $20 \mu \mathrm{g} / \mathrm{mL}<\mathrm{IC}_{50}<50 \mu \mathrm{g} / \mathrm{mL}$, low if $50 \mu \mathrm{g} / \mathrm{mL}<\mathrm{IC}_{50}<200 \mu \mathrm{g} / \mathrm{mL}$, and no cytotoxicity if $\mathrm{IC}_{50}>200 \mu \mathrm{g} / \mathrm{mL}$ [27]. Based on these cut-off points, the EL-EA fraction depicted strong cytotoxicity against adenocarcinomic human alveolar basal epithelial cells A549 ( $\left.\mathrm{IC}_{50}=8.27 \mu \mathrm{g} / \mathrm{mL}\right)$. In addition, the same fraction showed moderate cytotoxicity on $\mathrm{HeLa}\left(\mathrm{IC}_{50}=28.27 \mu \mathrm{g} / \mathrm{mL}\right)$. As previously observed with antibacterial activities, EL-EA displayed noteworthy anticancer potential, suggesting their potential use in the fighting against the double burden of infectious diseases and cancers. To the best of our knowledge, the present investigation reports for the first time the antibacterial activity and antiproliferative potential of E. lanceolatus. However, some species of the genus Echinops (Asteraceae), such as Echinops giganteus and Echinops grijsii, are well known to have significant anti-tumor and anti-infective effects [6]. The present study provides additional information on the antibacterial and cytotoxic properties of the aerial parts of E. lanceolatus, membership of the Echinops genus and Asteraceae family. The biological properties of E. lanceolatus, and particularly the EL-EA fraction recorded, could be attributed to the presence of structurally diverse secondary metabolites. Several phytochemicals have displayed functional activities that imply they could be responsible for a significant role in preventing a broad range of chronic diseases. However, the bioactivity of a plant extract does not depend exclusively on the presence of secondary metabolites. Indeed, the quantity, the quality, the type of extraction solvent, and possible interactions between the different constituents are some factors, which can also influence the activities [28-32]. The UPLC-ESI-MS/MS analysis of EL-EA revealed the presence of many compounds of which 32 have been identified, as shown in Table 2. The identified chemical compounds were mainly phenolic acids, flavonoids, lignan, organic acids, and fatty acids. The biological effects of these groups of compounds are no longer to be demonstrated. The bioactivity of identified compounds has been widely reported in the literature.

Some of the identified compounds including quinic acid, apigenin, apigenin-7-O-glucoside, kaempferol, and dicaffeoylquinic acid are common to members of the Echinops genus and Asteraceae family [6]. Several studies documented on biological activities (including antimicrobial and antiproliferative properties) of organic acids (succinic and dihydrobenzoic acids) [33-36] and phenolic compounds (cinnamic acid derivatives, quinic acid and derivatives) [37-42] identified in the present work. The flavonoids identified are not to be outdone. Flavonoids represent the largest group of naturally occurring polyphenols. They are common plant secondary metabolites widely used in phytomedicine to cure a wide range of ailments. Some are well-known antiproliferative phytochemicals such as dihydrokaempferol [43], flavanones glycosides (naringenin-7-O-glucoside, apigenin-7-O- $\beta$-D-glucoside, and naringin) [44-48]. Apigenin is another flavonoid class compound reported to exhibit several biological functions such as antibacterial, antiviral, anti-inflammatory, and antioxidant activities [49,50]. A well-known member of the apigenin family, with substantial biological properties, is the tri-substituted flavone rhoifolin [51], also identified in the present investigation. Other compounds identified including the phenylpropanoid coniferyl aldehyde [52], the dibenzyl butanediol lignan (-)-secoisolariciresinol [53,54], and fatty acids [55] have been revealed to possess valuable biological benefit against microbes and malign cells.

The biological activities of secondary metabolites identified in the present study underscore the correlation of the presence of these phytochemicals in E. lanceolatus and their antimicrobial and antiproliferative potential obtained against studied drug-resistant bacteria and human tumor cell 
lines (HeLa, A549, HepG2, HT-29), respectively. Each constituent could act by interacting with other constituents of the mixture, leading to the recorded activities. However, we can also hypothesize about the individual action of some compounds. The present study gives evidence of E. lanceolatus as a plant of pharmaceutical importance, a valuable source of biologically active compounds. Thorough investigations will allow the isolation and purification of each component along with an evaluation of their biological properties and action mechanisms.

\section{Materials and Methods}

\subsection{Chemicals and Reagents}

Trypticase Soy Agar (TSA) and Trypticase Soy Broth (TSB) (Qingdao Hope Bio-Technology, Qingdao, China) were used for bacteria culture. para-Iodonitrotetrazolium chloride (INT 98\%, Macklin, Shanghai, China) served as a bacterial growth indicator. Dimethyl sulfoxide (DMSO $\geq 99.0 \%$ ) obtained from Sinopharm Chemical Reagent (Shanghai, China) was used to dissolve extracts. Streptomycin (purity $>98 \%$, Abmole Biosciences, Houston, TX, USA) was used as the positive control for bacterial susceptibility testing. Dulbecco's Modified Eagle Medium (DMEM, Gibco, Beijing, China), Minimum Essential Medium Eagle (MEM, Hyclone, Logan, UT, USA), McCoy's 5A (Boster Biological Technology Co., Ltd., Pleasanton, CA, USA), and Ham's F12 K (Procell Life Science \& Technology Co., Ltd., Wuhan, China) were used for cancer cells culture. Other reagents for cell culture including fetal bovine serum (FBS), Sulforhodamine B (SRB), glutamine, and penicillin were obtained from Sigma-Aldrich (St. Louis, $\mathrm{MO}, \mathrm{USA})$.

\subsection{Plant Material}

The aerial parts of Echinops lanceolatus Matt F. (Asteraceae) were collected in Bangangté (West Region, Cameroon), coordinates ( $\left.5.1444^{\circ} \mathrm{N}, 10.5240^{\circ} \mathrm{E}\right)$, in July 2018. The fresh plant was cleaned with water, cut into fine parts, and then air-dried away from direct sunlight. Next, the air-dried plant was crushed and the resulting powder packed for further experiments. The plant sample was identified and authenticated at the National Herbarium of Cameroon (HNC, Yaoundé, Cameroon) with the kind assistance of M. Eric Ngansop (Taxonomist, HNC), where a voucher specimen was lodged under a reference number (14148SRF-CAM and 35113/HNC).

\subsection{Extraction Procedure}

Air-dried powder (100 g) of plant sample was macerated into methanol (MeOH) for $24 \mathrm{~h}$, followed by ultrasound-assisted extraction (KQ-500DE, Kunshan Ultrasonic Instrument Co., Ltd.) for $30 \mathrm{~min}$. The mixture was filtered using Whatman paper grade 1 . The same procedure was repeated twice with the remaining residue. The overall filtrate was evaporated under vacuum in a rotary evaporator at reducing pressure and temperature (below $45^{\circ} \mathrm{C}$ ) to yield $7.5 \mathrm{~g}$ of an oily dark extract. The partitioning was carried out according to the scheme previously described [56]. In brief, $\mathrm{MeOH}$ extract was suspended in deionized water to make a $95 \%$ aqueous solution. Afterward, a successive depletion was performed using solvents of increasing polarity including $n$-hexane, dichloromethane (DCM), ethyl acetate (EA), $n$-butanol $(n-\mathrm{BuOH})$, and finally water $\left(\mathrm{H}_{2} \mathrm{O}\right)$, to afford fractions. Corresponding fractions were evaporated in vacuo to yield the residues of $0.84 \mathrm{~g}, 0.56 \mathrm{~g}, 0.35 \mathrm{~g}, 1.85 \mathrm{~g}$, and $2.3 \mathrm{~g}$, respectively. $\mathrm{MeOH}$ extract and fractions were kept at $4{ }^{\circ} \mathrm{C}$ for future uses.

\subsection{UPLC-ESI-MS/MS Analysis}

A Q Exactive Orbitrap ${ }^{\circledR}$ LC-MS/MS (Thermo Fisher Scientific, San Jose, CA, USA) mass spectrometer coupled with a Vanquish UPLC system (Thermo Fisher Scientific, San Jose, CA, USA) was employed for the LC-MS analysis, which was equipped with an ESI source. The separation of the EL-EA fraction was acquired with a Hypersil Gold column (C18) column $(150 \times 2.1 \mathrm{~mm}, 5 \mu \mathrm{m})$ at $25^{\circ} \mathrm{C}$. The injection volume of the sample was $1 \mu \mathrm{L}$. Scan range $\mathrm{m} / \mathrm{z}$ 70-1050; ESI Spray Voltage: $3.2 \mathrm{kV}$; Sheath 
gas flow rate: 35 (arbitrary units); Aux Gas flow rate: 10 (arbitrary units); Capillary Temp: $320{ }^{\circ} \mathrm{C}$. Polarity: negative; MS/MS data-dependent scans. The mobile phase B and the used gradient condition are shown in Table 3.

Table 3. Gradient condition for UPLC-ESI-MS/MS analysis.

\begin{tabular}{ccc}
\hline Time & $\begin{array}{c}\text { Phase A } \mathbf{( 5 m M} \text { Ammonium } \\
\text { Acetate, } \mathbf{p H} \text { 9) }\end{array}$ & $\begin{array}{c}\text { Phase B (50\% ACN, 10mM } \\
\text { Ammonium Acetate, pH 9) }\end{array}$ \\
\hline 0.00 & $98 \%$ & $2 \%$ \\
1.50 & $98 \%$ & $2 \%$ \\
12.00 & $0 \%$ & $100 \%$ \\
14.00 & $0 \%$ & $100 \%$ \\
14.10 & $98 \%$ & $2 \%$ \\
16.00 & $98 \%$ & $2 \%$ \\
\hline
\end{tabular}

Compounds in EL-EA were identified by comparing the retention time, parent ion, and mass fragments with available standards in databases (ChemSpider, mzCloud, mzVault, HMDB, and PubChem) and/or literature data [9-21].

\subsection{Antibacterial Assay}

\subsubsection{Bacterial Strains}

Eight drug-resistant bacterial strains were examined for their sensitivity to crude $\mathrm{MeOH}$ extract and fractions. They were obtained from CCTCC (China Center for Type Culture Collection), CMCC (Center for Medical Culture Collection), and ATCC (American Type Culture Collection). These strains included two Gram-positive (Enterococcus faecalis ATCC29212 and Staphylococcus aureus CCTCC AB91093) and six Gram-negative bacteria (Acinetobacter baumannii ATCC19606, Enterobacter cloacae ATCC700323, Escherichia coli CCTCC AB93154, Klebsiella pneumoniae CMCC(B)46117, Pseudomonas aeruginosa ATCC9027, and Salmonella enterica CCTCC AB94018). The WHO [2] has classified the selected strains as priorities in the research for antibacterial agents.

The studied bacteria were maintained on agar slant at $4^{\circ} \mathrm{C}$ and each bacteria strain was subcultured (activation) at $37^{\circ} \mathrm{C}$ for $18-24 \mathrm{~h}$ on fresh appropriate agar plates $24 \mathrm{~h}$ before any antibacterial assay. Trypticase Soy Agar (TSA) was used for the activation of studied microorganisms, whereas Trypticase Soy Broth (TSB) was taken on for MIC and MBC determinations. Bacteria inoculum was initially prepared at McFarland 0.5, equivalent to $1.5 \times 10^{8} \mathrm{CFU} / \mathrm{mL}$.

\subsubsection{INT Colorimetric Assay for MIC and MBC Determinations}

Bacterial susceptibility testing was performed by broth microdilution in 96-well microplates, using para-iodonitrotetrazolium chloride (INT) as a bacterial growth indicator. INT acts as an electron acceptor and reacts with dehydrogenases released by bacteria during the kinetic growth to form an insoluble pink-colored formazan. The assay was carried out according to the previously described protocol [29-32]. Briefly, the extracts were dissolved beforehand in the DMSO/TSB mixture. The final concentration of DMSO was less than $2.5 \%$; this concentration is innocuous to bacterial growth. One hundred microliters of the solution were then added to the same volume of TSB in the wells of 96-well microplates followed by a two-fold serial dilution. The next step consisted of adding $100 \mu \mathrm{L}$ of bacterial suspension $\left(1.5 \times 10^{6} \mathrm{CFU} / \mathrm{mL}\right)$ prepared in TSB. The plates were covered with a sterile plate sealer, then mixed by shaking for $10 \mathrm{~min}$, and finally incubated at $37^{\circ} \mathrm{C}$ for $18 \mathrm{~h}$. The experiment was done in triplicate and repeated thrice. MIC was considered as the lowest concentration of the plant extract that prevented the visible growth of the tested bacteria. The growth of bacterial cells in each of the wells was confirmed by color change after the addition of $40 \mu \mathrm{L}$ of INT $0.02 \%(\mathrm{w} / \mathrm{v})$. In the absence of bacterial growth inhibition, the INT changed from clear to pink. Wells with DMSO alone 
as well as wells without any treatment were used as negative controls. Streptomycin was used as a positive control.

The MBC was determined after subculture of $50 \mu \mathrm{L}$ (of wells content corresponding to values $\geq \mathrm{MIC}$ ) in $150 \mu \mathrm{L}$ of TSB contained in new 96-well microplates, followed by incubation $\left(37^{\circ} \mathrm{C}\right)$ for $48 \mathrm{~h}$. Then, INT was used as the abovementioned to reveal bacterial growth. The MBC was considered as the lowest concentration of the sample, which prevents a color change after the addition of INT, corresponding to the total killing effect of bacteria cells [29-32].

\subsection{In Vitro Antiproliferative Assays}

Antiproliferative properties of E. lanceolatus extracts were performed on four human tumor cell lines provided by the China Center for Type Culture Collection (CCTCC). These included HepG2 (human liver cancer cell line), HeLa (cervical cancer cells), HT-29 (human colon cancer cell line), and A549 (adenocarcinomic human alveolar basal epithelial cells). Cells were maintained in an adequate medium: Dulbecco's Modified Eagle Medium (DMEM) for HepG2, Minimum Essential Medium Eagle (MEM) for HeLa, McCoy's 5A for HT-29, and Ham's F12 K for A549. Each culture medium was supplemented with $10 \%$ FBS, glutamine $(2 \mathrm{mM})$ and $1 \%$ penicillin $(100 \mathrm{U} / \mathrm{mL})$-streptomycin $(100 \mu \mathrm{g} / \mathrm{mL})$. Moreover, the cell lines were sub-cultured twice a week and incubated in a moistened atmosphere at $37{ }^{\circ} \mathrm{C}$ with $5 \% \mathrm{CO}_{2}$ and $90 \%$ relative humidity. Hematocytometer and phase-contrast microscopy were used for the counting of viable cells. The cells at the exponential growth phase (beyond 80\% confluence) were exploited for cell antiproliferative testing [57].

SRB colorimetric assay was used to investigate the antiproliferative properties of the plant extracts on the aforementioned cell lines, according to the previously described protocol [57,58]. IC 50 was determined and considered as the concentration of plant extract required to inhibit $50 \%$ of the cell proliferation and was calculated by plotting the percentage survival versus the concentrations, using GraphPad Prism 8.0.1. Each test sample solution was performed in triplicate, in a single experiment.

\subsection{Statistical Analysis}

All tests were done in triplicate and the data obtained from antiproliferative assays were analyzed using GraphPad Prism 8.0.1 software (GraphPad., San Diego, CA, USA).

\section{Conclusions}

Our findings revealed the antibacterial potential and antiproliferative activities of E. lanceolatus crude methanolic extract and subsequent partition fractions ( $n$-hexane, dichloromethane, ethyl acetate, and $n$-butanol). The ethyl acetate fraction was found to be the most effective one, and 32 phytochemicals have been identified in this fraction, of which quinic acid and derivatives, dihydrokaempferol, naringenin-7-O-glucoside, apigenin-7-O-glucoside, naringin, apigenin, rhoifolin, coniferyl aldehyde, and secoisolariciresinol are well documented for their antimicrobial and antiproliferative properties. These make substantial evidence to consider E. lanceolatus as a plant of biological importance, a valuable source for anti-infective and antitumor agents.

Author Contributions: Conceptualization, M.-Q.G.; methodology, A.J.S. and Y.-L.Z.; formal analysis, M.-Q.G., A.J.S., Y.-L.Z., and Y.-B.X.; investigation, A.J.S. and Y.-L.Z.; data curation, M.-Q.G., A.J.S., Y.-L.Z., and Y.-B.X.; writing-original draft preparation, A.J.S.; writing—review and editing, M.-Q.G.; supervision, M.-Q.G.; project administration, M.-Q.G.; funding acquisition, M.-Q.G. All authors have read and agreed to the published version of the manuscript.

Funding: This research was jointly funded by the Chinese Academy of Sciences (CAS), Grant No.2018PB0089 to A.J.S. and the Major Project for Special Technology Innovation of Hubei Province, Grant No. 2017AHB054 to M.-Q.G.

Acknowledgments: We would like to thank Mbuntcha Gueaba Helene for helping with the collection of the plant sample. We are grateful to Eric Ngansop (Taxonomist, National Herbarium of Cameroon), who authenticated the plant sample. We also thank Guilin Chen for critically revising the manuscript before submission. 
Conflicts of Interest: The authors declare no conflicts of interest. The funders had no role in the design of the study; in the collection, analyses, or interpretation of data; in the writing of the manuscript, or in the decision to publish the results.

\section{References}

1. Bray, F.; Ferlay, J.; Soerjomataram, I.; Siegel, R.L.; Torre, L.A.; Jemal, A. Global cancer statistics 2018: GLOBOCAN estimates of incidence and mortality worldwide for 36 cancers in 185 countries. CA Cancer J. Clin. 2018, 68, 394-424. [CrossRef] [PubMed]

2. World Health Organization. Prioritization of Pathogens to Guide Discovery, Research and Development of New Antibiotics for Drug-Resistant Bacterial Infections, Including Tuberculosis; WHO/EMP/IAU/2017.12; World Health Organization: Geneva, Switzerland, 2017.

3. Yu, Z.; Tang, J.; Khare, T.; Kumar, V. The alarming antimicrobial resistance in ESKAPEE pathogens: Can essential oils come to the rescue? Fitoterapia 2020, 140, 104433. [CrossRef] [PubMed]

4. Chen, G.; Huang, B.X.; Guo, M. Current advances in screening for bioactive components from medicinal plants by affinity ultrafiltration mass spectrometry. Phytochem. Anal. 2018, 29, 375-386. [CrossRef] [PubMed]

5. Sarker, S.D.; Nahar, L. Computational Phytochemistry, 1st ed.; Elsevier: Amsterdam, The Netherlands, 2018; p. 364.

6. Bitew, H.; Hymete, A. The genus Echinops: Phytochemistry and biological activities: A review. Front. Pharm. 2019, 10, 1234. [CrossRef]

7. Royal Botanical Garden (KEW). Echinops mildbraedii (Echinops lanceolatus). Available online: http://www. plantsoftheworldonline.org/taxon/urn:lsid:ipni.org:names:202586--1 (accessed on 13 December 2019).

8. Roskov, Y.; Ower, G.; Orrell, T.; Nicolson, D.; Bailly, N.; Kirk, P.M.; Bourgoin, T.; DeWalt, R.E.; Decock, W.; Nieukerken, E.; et al. Species 2000 E ITIS Catalogue of Life, 2019 Annual Checklist; Species 2000: Naturalis, Leiden, The Netherlands, 2019.

9. Liu, W.P.; Li, C.Y.; Huang, J.; Liao, J.Z.; Ma, W.J.; Chen, H.Y.; Rui, W. Identification of biomarkers in urine of rats with spleen Qi deficiency and biological significance. Zhongguo Zhong Yao Za Zhi Zhongguo Zhongyao Zazhi China J. Chin. Mater. Med. 2017, 42, 4855-4863. [CrossRef] [PubMed]

10. Deshpande, S.; Matei, M.F.; Jaiswal, R.; Bassil, B.S.; Kortz, U.; Kuhnert, N. Synthesis, structure, and tandem mass spectrometric characterization of the diastereomers of quinic acid. J. Agric. Food Chem. 2016, 64, 7298-7306. [CrossRef]

11. Gruz, J.; Novák, O.; Strnad, M. Rapid analysis of phenolic acids in beverages by UPLC-MS/MS. Food Chem. 2008, 111, 789-794. [CrossRef]

12. Bondia-Pons, I.; Barri, T.; Hanhineva, K.; Juntunen, K.; Dragsted, L.O.; Mykkänen, H.; Poutanen, K. UPLC-QTOF/MS metabolic profiling unveils urinary changes in humans after a whole grain rye versus refined wheat bread intervention. Mol. Nutr. Food Res. 2013, 57, 412-422. [CrossRef]

13. Clifford, M.N.; Johnston, K.L.; Knight, S.; Kuhner, N. Hierarchical scheme for LC-MSn identification of chlorogenic acids. J. Agric. Food Chem. 2003, 51, 2900-2911. [CrossRef]

14. Kuhnert, N.; Jaiswal, R.; Matei, M.F.; Sovdat, T.; Deshpande, S. How to distinguish between feruloyl quinic acids and isoferuloyl quinic acids by liquid chromatography/tandem mass spectrometry. Rapid Commun. Mass Spectrom. 2010, 24, 1575-1582. [CrossRef]

15. Zhong, R.F.; Xu, G.B.; Wang, Z.; Wang, A.M.; Guan, H.Y.; Li, J.; He, X.; Liu, J.H.; Zhou, M.; Li, Y.J.; et al. Identification of anti-inflammatory constituents from Kalimeris indica with UHPLC-ESI-Q-TOF-MS/MS and GC-MS. J. Ethnopharmacol. 2015, 165, 39-45. [CrossRef]

16. Moqbel, H.; El Hawary, S.S.E.D.; Sokkar, N.M.; El-Naggar, E.M.B.; El Boghdady, N.; El Halawany, A.M. HPLC-ESI-MS/MS characterization of phenolics in Prunus amygdalus, cultivar "umm alfahm" and its antioxidant and hepatoprotective activity. J. Food Meas. Charact. 2018, 12, 808-819. [CrossRef]

17. Kammerer, B.; Kahlich, R.; Biegert, C.; Gleiter, C.H.; Heide, L. HPLC-MS/MS analysis of willow bark extracts contained in pharmaceutical preparations. Phytochem. Anal. 2005, 16, 470-478. [CrossRef] [PubMed]

18. Song, H.P.; Zhang, H.; Fu, Y.; Mo, H.Y.; Zhang, M.; Chen, J.; Li, P. Screening for selective inhibitors of xanthine oxidase from Flos chrysanthemum using ultrafiltration LC-MS combined with enzyme channel blocking. J. Chromatogr. B 2014, 961, 56-61. [CrossRef] [PubMed] 
19. Mena, P.; Sánchez-Salcedo, E.M.; Tassotti, M.; Martínez, J.J.; Hernández, F.; Del Rio, D. Phytochemical evaluation of eight white (Morus alba L.) and black (Morus nigra L.) mulberry clones grown in Spain based on UHPLC-ESI-MS ${ }^{n}$ metabolomic profiles. Food Res. Int. 2016, 89, 1116-1122. [CrossRef]

20. Barreca, D.; Bellocco, E.; Caristi, C.; Leuzzi, U.; Gattuso, G. Flavonoid composition and antioxidant activity of juices from chinotto (Citrus myrtifolia Raf.) fruits at different ripening stages. J. Agric. Food Chem. 2010, 58, 3031-3036. [CrossRef]

21. Arivalagan, M.; Roy, T.K.; Yasmeen, A.M.; Pavithra, K.C.; Jwala, P.N.; Shivasankara, K.S.; Manikantan, M.R.; Hebbar, K.B.; Kanade, S.R. Extraction of phenolic compounds with antioxidant potential from coconut (Cocos nucifera L.) testa and identification of phenolic acids and flavonoids using UPLC coupled with TQD-MS/MS. LWT 2018, 92, 116-126. [CrossRef]

22. Seukep, A.J.; Kuete, V.; Nahar, L.; Sarker, S.D.; Guo, M. Plant-derived secondary metabolites as the main source of efflux pump inhibitors and methods for identification. J. Pharm. Anal. 2019. [CrossRef]

23. Kuete, V. Potential of Cameroonian plants and derived products against microbial infections: A review. Planta Med. 2010, 76, 1479-1491. [CrossRef]

24. Liu, Y.; Cao, Y.; Wang, T.; Dong, Q.; Li, J.; Niu, C. Detection of 12 common food-borne bacterial pathogens by TaqMan Real-Time PCR using a single set of reaction conditions. Front. Microbiol. 2019, 10, 222. [CrossRef]

25. Nikaido, H. Prevention of drug access to bacterial targets: Permeability barriers and active efflux. Science 1994, 264, 382-388. [CrossRef] [PubMed]

26. Wright, G.D. Bacterial resistance to antibiotics: Enzymatic degradation and modification. Adv. Drug Deliv. Rev. 2005, 10, 1451-1470. [CrossRef] [PubMed]

27. Kuete, V.; Efferth, T. African flora has the potential to fight multidrug resistance of cancer. Biomed Res. Int. 2015, 2015, 914813. [CrossRef] [PubMed]

28. Bruneton, J. Pharmacognosie: Phytochimie, Plantes Médicinales, 3rd ed.; Tec \& Doc: Paris, France, 1999; pp. 263-309.

29. Seukep, A.J.; Fankam, A.G.; Djeussi, D.E.; Voukeng, I.K.; Tankeo, S.B.; Noumedem, J.A.K.; Kuete, A.H.; Kuete, V. Antibacterial activities of the methanol extracts of seven Cameroonian dietary plants against bacteria expressing MDR phenotypes. Springerplus 2013, 2, 363. [CrossRef]

30. Seukep, A.J.; Ngadjui, B.T.; Kuete, V. Antibacterial activities of Fagara macrophylla, Canarium schweinfurthii, Myrianthus arboreus, Dischistocalyx grandifolius and Tragia benthamii against multi-drug resistant Gram-negative bacteria. Springerplus 2015, 4, 567. [CrossRef]

31. Seukep, A.J.; Sandjo, L.P.; Ngadjui, B.T.; Kuete, V. Antibacterial and antibiotic-resistance modifying activity of the extracts and compounds from Nauclea pobeguinii against Gram-negative multi-drug resistant phenotypes. BMC Complement. Altern. Med. 2016, 16, 193. [CrossRef]

32. Seukep, A.J.; Sandjo, L.P.; Ngadjui, B.T.; Kuete, V. Antibacterial activities of the methanol extracts and compounds from Uapaca togoensis against Gram-negative multi-drug resistant phenotypes. S. Afr. J. Bot. 2016, 103, 1-5. [CrossRef]

33. Vandal, J.; Abou-Zaid, M.M.; Ferroni, G.; Leduc, L.G. Antimicrobial activity of natural products from the flora of Northern Ontario, Canada. Pharm. Biol. 2015, 53, 800-806. [CrossRef]

34. Kima, J.E.; Seob, J.H.; Baec, M.S.; Baed, C.-S.; Yooe, J.C.; Bangf, M.A.; Choa, S.S.; Park, D.H. Antimicrobial constituents from Allium hookeri Root. Nat. Prod. Commun. 2016, 11, 237-238. [CrossRef]

35. Purohit, A.; Mohan, A. Antimicrobial effects of pyruvic and succinic acids on Salmonella survival in ground chicken. LWT 2019, 116, 108596. [CrossRef]

36. Kumar, R.; Chandar, B.; Parani, M. Use of succinic and oxalic acid in reducing the dosage of colistin against New Delhi metallo- $\beta$-lactamase- bacteria. Indian J. Med. Res. 2018, 147, 97-101. [CrossRef] [PubMed]

37. Gaglione, M.; Malgieri, G.; Pacifico, S.; Severino, V.; D’Abrosca, B.; Russo, L.; Fiorentino, A.; Messere, A. Synthesis and biological properties of caffeic acid-PNA dimers containing guanine. Molecules 2013, 18, 9147-9162. [CrossRef] [PubMed]

38. Pei, K.; Ou, J.; Huang, J.; Ou, S. p-Coumaric acid and its conjugates: Dietary sources, pharmacokinetic properties and biological activities. J. Sci. Food Agric. 2016, 96, 2952-2962. [CrossRef] [PubMed]

39. Abdallah, H.M.; Ezzat, S.M.; Dine, R.S.; Abdel-Sattar, E.; Abdel-Naim, A.B. Protective effect of Echinops galalensis against CCl4-induced injury on the human hepatoma cell line (Huh7). Phytochem. Lett. 2013, 6, 73-78. [CrossRef] 
40. Fraisse, D.; Felgines, C.; Texier, O.; Lamaison, J.L. Caffeoyl derivatives: Major antioxidant compounds of some wild herbs of the Asteraceae family. Food Nutr. Sci. 2011, 2, 181-192. [CrossRef]

41. Mijangos-Ramos, I.F.; Zapata-Estrellaa, H.E.; Ruiz-Vargas, J.A.; Escalante-Erosa, F.; Gómez-Ojeda, N.; García-Sosa, K.; Cechinel-Filho, V.; Meira-Quintão, N.L.; Pena-Rodríguez, L.M. Bioactive dicaffeoylquinic acid derivatives from the root extract of Calea urticifolia. Rev. Bras. Farm. 2018, 28, 339-343. [CrossRef]

42. Petropoulos, S.A.; Pereira, C.; Tzortzakis, N.; Barros, L.; Ferreira, I.C.F.R. Nutritional value and bioactive compounds characterization of plant parts from Cynara cardunculus L. (Asteraceae) cultivated in Central Greece. Front. Plant Sci. 2018, 9, 459. [CrossRef]

43. Zhang, Y.; Yan, G.; Sun, C.; Li, H.; Fu, Y.; Xu, W. Apoptosis effects of dihydrokaempferol isolated from Bauhinia championii on Synoviocytes. Evid. Based Complement. Altern. Med. 2018, 2018, 10. [CrossRef]

44. Harborne, J.B. The Flavonoids Advances in Research Since 1986, 1st ed.; Routledge, Chapman and Hall/CRC: Abingdon-on-Thames, UK, 2017; p. 676.

45. Wang, Y.; Xu, Z.; Huang, Y.; Wen, X.; Wu, Y.; Zhao, Y.; Ni, Y. Extraction, purification, and hydrolysis behavior of Apigenin-7-O-glucoside from Chrysanthemum morifolium tea. Molecules 2018, 23, 2933. [CrossRef]

46. Wang, H.; Li, Y.L.; She, W.Z.; Guo, G.Q.; Jiang, Z.Y.; Cen, Y.Z.; Fan, Z.Y. Studies on antiproliferative effect of flavones compounds isolated from Yao herb medicines. Zhong Yao Cai 2007, 30, 980-984. [PubMed]

47. Smiljkovic, M.; Stanisavljevic, D.; Stojkovic, D.; Petrovic, I.; Vicentic, J.M.; Popovic, J.; Grdadolnik, S.G.; Markovic, D.; Sankovic-Babice, S.; Glamoclija, J.; et al. Apigenin-7-O-glucoside versus apigenin: Insight into the modes of anticandidal and cytotoxic actions. EXCLI J. 2017, 16, 795-807. [CrossRef] [PubMed]

48. Chen, R.; Qi, Q.L.; Wang, M.T.; Li, Q.Y. Therapeutic potential of naringin: An overview. Pharm. Biol. 2016, 54, 3203-3210. [CrossRef] [PubMed]

49. Yan, X.; Qi, M.; Li, P.; Zhan, Y.; Shao, H. Apigenin in cancer therapy: Anti-cancer effects and mechanisms of action. Cell Biosci. 2017, 7, 50. [CrossRef] [PubMed]

50. Salehi, B.; Venditti, A.; Sharifi-Rad, M.; Kregiel, D.; Sharifi-Rad, J.; Durazzo, A.; Lucarini, M.; Santini, A.; Souto, E.B.; Novellino, E.; et al. The therapeutic potential of apigenin. Int. J. Mol. Sci. 2019, 20, 1305. [CrossRef] [PubMed]

51. Refaat, J.; Desoukey, Y.S.; Ramadan, M.A.; Kamel, M.S. Rhoifolin: A review of sources and biological activities. IJP 2015, 2, 102-109. [CrossRef]

52. Xu, J.P. Cancer Inhibitors from Chinese Natural Medicines, 1st ed.; CRC Press, Francis and Taylor Group: Abingdon, UK, 2016; p. 787.

53. Céspedes, C.L.; Avila, J.G.; García, A.M.; Becerra, J.; Flores, C.; Aqueveque, P.; Bittner, M.; Hoeneisen, M.; Martinez, M.; Silva, M. Antifungal and antibacterial activities of Araucaria araucana (Mol.) K. Koch heartwood lignans. Zeitschrift Naturforschung C 2006, 61, 35-43. [CrossRef]

54. Kezimana, P.; Dmitriev, A.A.; Kudryavtseva, A.V.; Romanova, E.V.; Melnikova, N.V. Secoisolariciresinol diglucoside of flaxseed and its metabolites: Biosynthesis and potential for nutraceuticals. Front. Genet. 2018, 9, 641. [CrossRef]

55. Dilika, F.; Bremner, P.D.; Meyer, J.J. Antibacterial activity of linoleic and oleic acids isolated from Helichrysum pedunculatum: A plant used during circumcision rites. Fitoterapia 2000, 71, 450-452. [CrossRef]

56. Parsaee, H.; Asilib, J.; Mousavic, S.H.; Soofi, H.; Emami, S.A.; Tayarani-Najarane, Z. Apoptosis induction of Salvia chorassanica root extract on human cervical cancer cell line. Iran J. Pharm. Res. 2013, 12, 75-83. [PubMed]

57. Chen, G.; Li, X.; Saleri, F.; Guo, M. Analysis of flavonoids in Rhamnus davurica and its antiproliferative activities. Molecules 2016, 21, 1275. [CrossRef]

58. Dzoyem, J.P.; Guru, S.K.; Pieme, C.A.; Kuete, V.; Sharma, A.; Khan, I.A.; Saxena, A.K.; Vishwakarma, R.A. Cytotoxic and antimicrobial activity of selected Cameroonian edible plants. BMC Complement. Altern. Med. 2013, 13, 78. [CrossRef] [PubMed]

(C) 2020 by the authors. Licensee MDPI, Basel, Switzerland. This article is an open access article distributed under the terms and conditions of the Creative Commons Attribution (CC BY) license (http://creativecommons.org/licenses/by/4.0/). 